\title{
Assessment of forest ecosystem service research trends and methodological approaches at global level: a meta-analysis
}

Wondimagegn Mengist ${ }^{1 *}$ (D) and Teshome Soromessa ${ }^{2}$

\begin{abstract}
Ecosystem service (ES) is a growing field of research characterized by an increase in publication number. The review was conducted to provide an overview of trends of forest ecosystem services (FES) research and methodological approach to studied FES. Currently, the number of publications on ES was more than 18,000 , but small publications were linked with FES. Based on the selection criteria, 41 peer-reviewed publications were screened to analyze the type of FES studied and the method used to quantify ES. The result showed that most of the research articles, to date, had focused largely on provisioning, regulating and cultural ecosystem services, which were timber production, water supply, carbon sequestration, and recreation. FES like a pollination, genetic resources, pest regulation, and aesthetic values have not been studied in any literature reviews. The review result showed that different studies used diverse methodological approaches and had inconsistent and scattered conclusions. From the selected studies, the majority of them were conducted in Europe and Asia. Particularly, the publication number from Ethiopia was very low and needs to conduct studies before the forest resources are further degraded.
\end{abstract}

Keywords: Ecosystem services, Ethiopia, Forest ecosystem services, Natural capital, Meta-analysis, Science direct

\section{Background}

Ecosystem services are "the benefits that people obtain from ecosystems" (MEA 2005). It is defined as "The direct and indirect contributions of ecosystems to human wellbeing" (TEEB 2010). Ecosystem services provide various materials and non-material benefits to human beings (Costanza et al. 1997; Nelson et al. 2009; Vizzarri et al. 2015; Englund et al. 2017). These services are grouped into four broad categories of provisioning, regulating, cultural and supporting ES. Provisioning services which are familiar part of the economy and includes goods obtained from ecosystems like food, fiber, fresh water, and genetic resources. Regulating services include benefits obtained from the regulation of an ecosystem processes, including air quality regulation, climate regulation, water regulation, an erosion regulation, a

\footnotetext{
*Correspondence: wondie21emu@yahoo.com; wondime2007@gmail. com

${ }^{1}$ Department of Natural Resource Management, Debre-Berhan University, Debre Berhan, Ethiopia

Full list of author information is available at the end of the article
}

pollination, and natural hazard regulation. Cultural services are the nonmaterial benefits that human beings are acquired from the ecosystem through aesthetic experience, reflection, recreation, the spiritual enrichment, and knowledge system and education. Supporting services are fundamental to maintain the conditions for life on Earth and include services like soil formation, photosynthesis, and nutrient cycling, and habitats for species (De Groot 2002; MEA 2005; Englund et al. 2017). Therefore, the flow of ES is determine the level of human-well beings, which is linked to ecosystem composition and function (Cruz-Garcia et al. 2016).

Ecosystem services as one field of studies began after the studies by Daily in 1997 and Costanza et al. in 1997 (Aznar-Sánchez et al. 2018). Later on, the concept is introduced to the political agenda by the MEA project in 2005; the TEEB in 2010 and the Intergovernmental Science-Policy Platform on Biodiversity and Ecosystem Services (IPBES) in 2012. They are benchmarks that turned the concept into a political instrument to achieve the sustainable use of natural resources. They can benefit 
policy-makers to make an informed decision that is based on scientific evidence (Aznar-Sánchez et al. 2018). Since the publication of the MEA document in 2005, ecosystems have become widely recognized as natural capital assets that support and supply services which are highly valuable to the human well beings. As a result, there is a growing appreciation worldwide on the importance of an ecosystem to human welfare by providing goods and services, and on the impact of human actions on ecosystems (Ojea et al. 2012). The ecosystem that provides services is sometimes referred to as 'natural capital'. Thus, "ecosystem services refer to the relative contribution of natural capital to the production of various human benefits, in interaction with the other forms of capital". Ecosystem services can flow to the human wellbeing through an interaction process (Harmácková and Vackár 2015; Costanza et al. 2017) (See Additional file 1: Table S2). To make more specific about the natural capital and ecosystem services, various ecosystem classification was done for scientific analysis, economic valuation and policy issues. For instance, following Daily (1997) and Costanza et al. (1997), various classification schemes were developed such as MEA in 2005 classified into 22 under four groups: provisioning, regulating, cultural and supporting. TEEB (2010) uses a classification that includes 22 ES grouped into four main categories: provisioning, regulating, habitat, and cultural and amenity. The important difference between MEA and TEEB is that the TEEB classification omitted supporting services-is considered it as a subset of ecosystem processes and the inclusion of habitat services category under its classification schemes. The Common International Classification of Ecosystem Services (CICES) was developed to provide a hierarchically consistent and science-based classification to be used for natural capital accounting purposes (Costanza et al. 2017).

The continued and the rapid degradation and unsustainable use of ecosystem services all over the world put the health and livelihoods of millions of people at risk (Egoh et al. 2007; Aerts and Honnay 2011). These urges a sustainable way of management to balance the potential of forest ecosystem services with human needs. The balance between forest resource exploitation for human wellbeing and ecosystem conservation is a key to bring sustainable development (Rukundo et al. 2018). As a result, scientists and policy maker started to work together. Researcher, policy-maker, and practitioners develop an interest in ES that has come from several sources (Balvanera et al. 2014). The widely acknowledged source is perhaps the report of MEA by the United Nations in 2005, which was the first comprehensive global assessment of the implications of ecosystem change for people (Cuni-Sanchez et al. 2016). Following the MEA 2005) report, the ecosystem services concept got broader attention worldwide. The existence of strong link between biodiversity and ecosystem services lead to the creation of TEEB which was initiated by UNEP (United Nations Environment Programme) in 2010, EC (European Commission), and the Intergovernmental Platform on Biodiversity and Ecosystem Services (IPBES) in 2012. In addition, an international conference was held on ecosystem services. The growing on the importance of ecosystem services fields at the global level has also resulted in the launch of new journal type with a title of Ecosystem Services in 2012 (Braat and de Groot 2012; Ninan and Inoue 2013b), and special issue of the journal was opened which is Ecological Economics on ecosystem services valuation. The aim is strengthening a sciencepolicy interface that can contribute to conserve and sustainably use the biodiversity resources, prolonging human well-being and to bring sustainable development (García-nieto et al. 2013; Balvanera et al. 2014). During the past decade thus, ecosystem service research is a rapidly evolving field and the number of publication is rising (Fisher et al. 2008).

Ecosystem services concept was initially introduced to raise public awareness on the importance of biodiversity for human existence and to conserve biodiversity. Forest is thus, the main sources of ecosystem services and are fundamental for life support systems (Vizzarri et al. 2015). Forest ecosystem services have direct and indirect services. Direct provisioning services are timber, fiber, bioenergy, grazing, clean water, traditional medicines, and the socio-cultural benefits that include ritual services, aesthetic, and ecotourism. Forests have also regulatory services such as erosion regulation, landslide control, and regulation of water, air, drought, disease, and climate through carbon sequestration. Supporting services from forests can include pollination, nutrient cycling, and sources of propagates for shade and agroforestry trees, bio-control of agricultural pests, and biodiversity conservation (Power 2010; Tadesse et al. 2014).

Forest plays a major role in global climate regulation through sequestration of carbon and serves as a carbon sinks during its most stage of development. It can also serve as a habitat for various plants and animal species, for mitigating pollution, flood control and other ecosystem services (Deal et al. 2012). Tropical forests are one of the most diverse in biodiversity and ecosystems on earth. Biodiversity is widely acknowledged that it has a significant role in the provision of various ecosystem services to people (Beenhouwer et al. 2013; Tekalign et al. 2018). It maintains the indigenous culture, provides means of livelihoods for millions of people, and sequestering about $40 \%$ of the global terrestrial carbon (Tekalign et al. 2018). However, the high rate of deforestation and degradation 
are eroding the biodiversity composition, function, and structures of forests. The degradation process causes a decline in resistance of forests to natural or anthropogenic disturbances (Brockerhoff et al. 2017). These, in turn, caused a decline both in quality and quantity of services that people have from forests because biodiversity and ecosystem services are inseparably linked, and both are declining at the global level (Egoh et al. 2007; Aerts and Honnay 2011; Balvanera et al. 2014; Tekalign et al. 2018). These are caused by human-induced effects such as forest removal, degradation, and encroachments which caused a decline in biodiversity and ecosystem services (Tadesse et al. 2014; Tolessa et al. 2017). According to Aznar-Sánchez et al. (2018), the expansion of farming land, urbanization, and effects of climate change also threaten the forest resources and its service flow. Thus, the forest resource needs management that sustainably prolongs the ecosystem services. To introduce sustainable forest resource to maintain an ecosystem services, understanding of their importance at the spatial and societal level is critical. Understanding the types of forest-based ecosystem service which has importance to human wellbeing is the main part of ecosystem service assessments.

The reviewed work is a systematic study dealing with ecosystem services of forests. Particularly, the study focuses on answering the following two questions: (1) what are the trends of forest ecosystem services in comparison to ecosystem services; (2) what are the methodological approaches employed to value FES. In the discussion section, the research gaps of the selected studies and future research needs are explained. Although the monetary value for forest ES has limitation and technical challenges (Spangenberg and Settele 2010; Luck et al. 2012), representing FES values in monetary terms has more role to expand the sustainable utilization of resources. Therefore, the main aim of the present study was to assess and gather the available knowledge and information on forest ecosystem services, its monetary value, and areas demanding further works through a meta-analysis of individual case studies from the peerreviewed English journal articles. The specific aim is to (1) provide and develop timely and relevant scientific knowledge regarding ecosystem services and forest ecosystem services; (2) quantify the monetary value and the methodology used for forest ecosystem services; and (3) identifying and discussing future research areas of forest ecosystem services.

\section{Methodology}

\section{Data collection}

Data were collected from the literature found in Scopus and Science Direct databases. The search focus on peer-reviewed journal articles written in English, excluding books and book series, conference proceedings, editorials, letters, patents, reference works, research notes and trade publications. The search was conducted in December 2018 and peer-reviewed journal articles cover those published between 2005 (coinciding with the publication of the Millennium Ecosystem Assessment synthesis reports) up to 2018 that focus on ecosystem services and forest ecosystem services in a title, keywords or abstracts. It also has been carried out a general search of articles on forest ecosystem services indexed by Google scholar during the same period.

\section{The term used and frameworks of data collection}

A list of research articles was generated using "ecosystem service" both on title and title-abstract-keyword. The next search was using the filtering process of "forest ecosystem services" both on title and title-abstract-keyword. It must be taken into consideration is that different search parameters would give different results. Figure 2 below presents a flow diagram of the selection process of publications for this review paperwork. It is based on the PRISMA (Preferred Reporting Items for Systematic Reviews and Meta-Analyses) rules and templates (Moher et al. 2010). The selection was based on the following criteria. In the first step, a research article that constitutes forest ecosystem services or forest services in the article title was selected by excluding conference/proceedings and books. The literature resulting from the keyword search was narrowed down by reading the abstracts and screening the texts. It limits studies that explicitly stated forest-related ecosystem services and it excluded any paper dealing with ecosystems other than forests. Using the filtering process, the total number of articles found was 17,911 from Scopus and 6321 from science direct databases, without excluding duplicated articles. The second step was to include only case studies that took place on forest ecosystem services. This resulted in research articles of about 1911 from Scopus and 429 from science direct databases. The third step was to exclude publications that was reviewed articles and research papers that lack the quantification of forest ecosystem services either using InVEST or other economic valuation techniques. Document abstracts were read to evaluate the occurrence of the different forest ecosystem services and the monetary value of forest services. This help to ensure that the articles were included that focused on valuation, quantification, and mapping of forest ecosystem services, but were excluded when they did not meet the selection criteria. Duplicated articles were manually deleted. Therefore, 41 articles were selected for further analysis. For full transparency, a list of all publications retained for further analysis is provided in the Additional file 1: Table S1. 

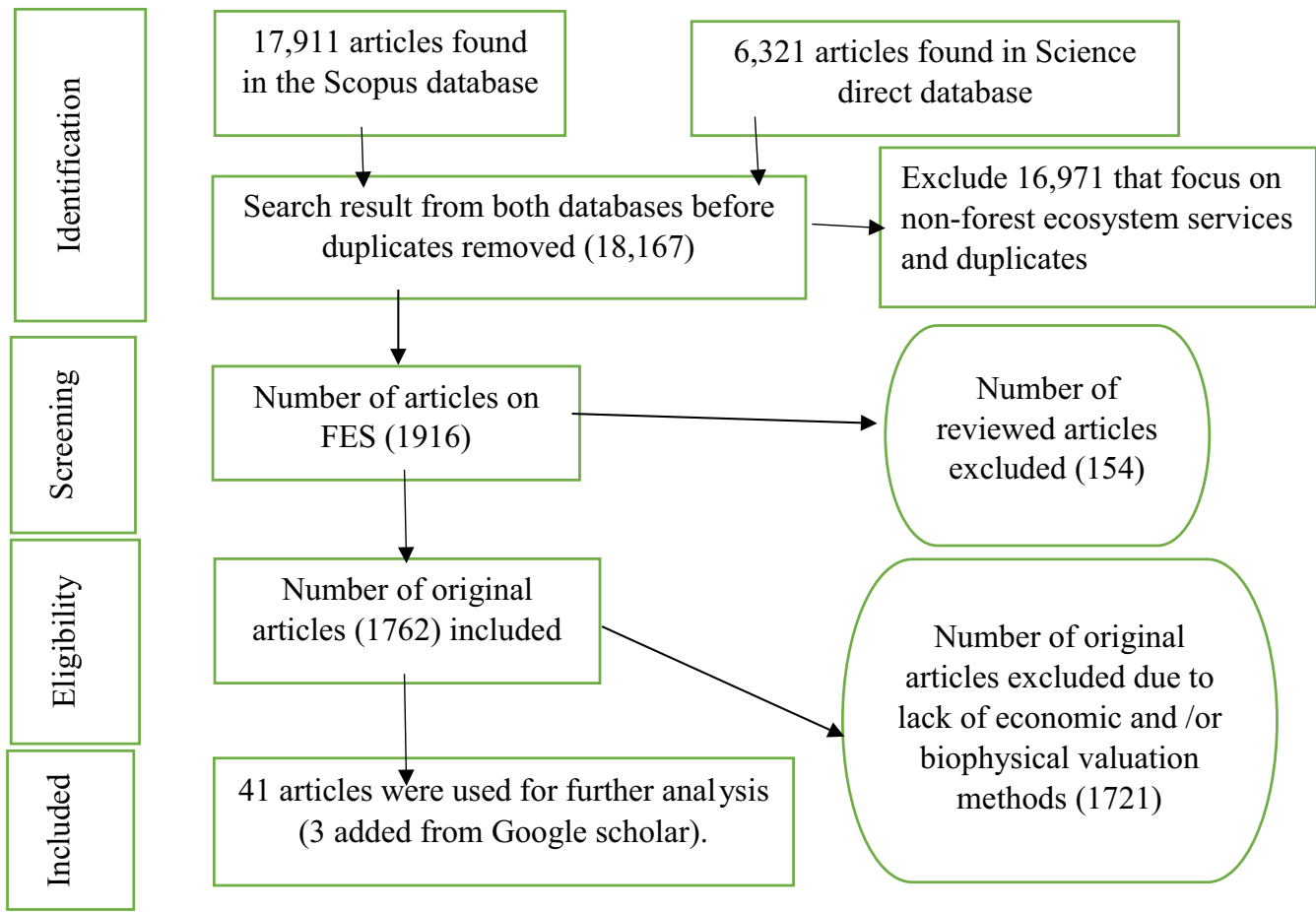

Fig. 1 The flow diagram for database search of publications for systematic reviews. This figure demonstrates the process of selecting the final articles related on the topic for further analysis. The number of articles was large in number, when the search was any ecosystem service research work. However, when the criteria is going to be more specific to FES and its methods used to quantify/qualify, mapping and value the ecosystem services, thus the size of the articles was reduced Source: Modified from Moher et al. (2010).

From the final list of the papers, there were various types of forest ecosystem services have been analyzed, as most of the reviewed papers address on several forest ecosystem services. It is conceded that these publications do not comprise every single paper that stated forest ecosystem services, but they do allow one to gain a broad overview of the most significant literature and to draw reliable conclusions on recent approaches to forest ecosystem services research and its methodology used to assess the various ecosystem services. Science direct includes a lower number of indexed journals than Scopus however, Scopus is easily accessible, has tools to view and analysis data, and downloading data in various ways (Aznar-Sánchez et al. 2018) (Fig. 1).

\section{Data analysis and presentation}

The data gathered in this review were analyzed using descriptive statistics. For each of the identified studies, therefore, the following information has been coded for further analysis: types of ecosystem services investigated, the methodology used to assess the ecosystem services and monetary estimates, scale, year of study, institution, country, and journal. Later each forest ecosystem services was classified to provisioning, regulating, cultural and supportive services based on the millennium ecosystem assessment categories. After the FES type was identified, statistics of the four ES categories were calculated and displayed using different tables and figures. The results were drawn up in order to view and analyze the data using an Excel spreadsheet.

\section{Results and discussions}

\section{Trends of scientific research production on ES}

The two databases had no equal publication number using the same search terms. Table 1 summarizes the main outcomes of the literature review both on ecosystem and forest ecosystem services from 2005 until December 31, 2018. From the first search of research articles using a combinations of the term "ecosystem service" and title-abstract or keyword "ecosystem services", about 6321 articles (5656 research and 665 reviewed articles) were found in science direct data basis and from Scopus data basis, a total of 17,911 articles of which 15,927 research and 1984 reviewed articles were found. Comparatively, the Scopus database had more published articles in its archive than the science direct database. In all search engines except the "supporting services" OR "supporting ecosystem services", the Scopus had larger number of published articles than science direct. 
Table 1 The number of publications on ecosystem and forest ecosystem services using Scopus and science direct databases from 2005 to 2018

\begin{tabular}{|c|c|c|c|c|c|c|c|c|}
\hline \multicolumn{2}{|c|}{ Review section } & \multirow[t]{2}{*}{ Search terms } & \multicolumn{3}{|c|}{ Scopus } & \multicolumn{3}{|c|}{ Science direct } \\
\hline & & & $O A$ & RA & Total & $\mathrm{OA}$ & RA & Total \\
\hline \multirow[t]{5}{*}{1} & Ecosystem services at world level & "Ecosystem services" & 15,927 & 1984 & 17,911 & 5656 & 665 & 6321 \\
\hline & Ecosystem service categories & "Provisioning services" OR "provisioning ecosystem services" & 473 & 53 & 526 & 235 & 27 & 262 \\
\hline & & "Supporting services" OR "supporting ecosystem services" & 423 & 44 & 467 & 868 & 72 & 940 \\
\hline & & "Cultural services" OR "cultural ecosystem services" & 828 & 96 & 924 & 379 & 42 & 421 \\
\hline & & "Regulating services" OR "regulating ecosystem services" & 442 & 45 & 487 & 214 & 23 & 237 \\
\hline \multirow[t]{5}{*}{2} & Forest ecosystem services & "Forest service" OR "forest ecosystem services" & 1762 & 149 & 1911 & 421 & 8 & 429 \\
\hline & Forest ecosystem services at world level & "Provisioning services" AND"forests" & 102 & 10 & 112 & 44 & 3 & 47 \\
\hline & & "Regulating services" AND "forests" & 93 & 8 & 101 & 39 & 3 & 42 \\
\hline & & "Habitat services" OR "supporting services" AND "forests" & 48 & 3 & 51 & 30 & 1 & 31 \\
\hline & & $\begin{array}{l}\text { "Cultural services" OR"tourism services" OR "recreational } \\
\text { services" AND"forests" }\end{array}$ & 118 & 9 & 127 & 292 & 30 & 322 \\
\hline \multirow[t]{3}{*}{3} & Ecosystem services in Ethiopia & "Ecosystem services" AND "Ethiopia" & 102 & 5 & 107 & 46 & 2 & 48 \\
\hline & & "Forest ecosystem services" AND "Ethiopia" & 2 & 0 & 2 & 1 & 0 & 1 \\
\hline & & "Ecosystem services" AND "forests" AND "Ethiopia" & 51 & 0 & 51 & 24 & 0 & 24 \\
\hline
\end{tabular}

N.B. OA: original articles; RA: reviewed articles

Using the second search engine, "forest service" OR "forest ecosystem services", the publication amount from Scopus database was larger than the science direct database. About 1911 publication (1762 research articles and 149 reviewed articles) and 429 articles (421 research and 8 reviewed articles) were found from Scopus and science direct databases, respectively. Based on the four main categories of ES, most of the articles were cover cultural, provisioning and regulating ES. The number of studies addressing habitat/supporting ES were small, which might be linked with the absence of well-developed methodology, unlike the others.

From the third searching engine category, "ecosystem services" AND "Ethiopia", "forest ecosystem services" AND "Ethiopia", and "ecosystem services" AND "forests" AND "Ethiopia", relatively Scopus database had larger publication number. However, when the search term was becoming more specific to the types of ES, the amount of publication was too small. For example, based on "forest ecosystem services" AND "Ethiopia" searching terms, only two and one research articles were found from Scopus and science direct databases (see Table 1).

Figure 2 shows a comparison between the numbers of published research on forest ecosystem services in particular and on ecosystem services in general from the science direct database. In order to compare the growth in the number of articles within each line of research, the annual accumulation of publication was calculated. Based on publication number, in 2005 and 2018, ES increased from 23 to 1291, and FES from 21 to 50 publication using science direct database. The result showed that there is an increment of research publication mainly on ecosystem services. Though the term ecosystem services existed before the 1970s, it has been mainstreamed in the scientific literature in 1990s (Costanza et al. 1997; Daily 1997). After the publication of the millennium assessment report in 2005, ecosystem research work became popular and exponentially increases (Fisher et al. 2008; Luck et al. 2012; Philipp et al. 2013). For instance, the number of publications on ecosystem services has grown exponentially from one in 1996 to more than ten per year to 2008 (Crossman et al. 2013).

Figure 3 shows the trends of forest ecosystem service publications. However, the amount of publication on forest ecosystem services was rising after 2009. From the last 3 years, the year 2017 had the highest number of articles (217 articles) than the year 2016 (184 articles) and 2018 (162 articles). The last year had the smallest article number than the previous 2 years in terms of its publication number.

Bojovic et al. (2013) reviewed journals during the 5 year period from 2006 to 2010 to identify research trends of forestry journals. They found out about 16,258 documents from 42 journals which were classified in 22 subdisciplines. However, none of these categories were linked to ecosystem services. This was due to the existence of various journal types that published forest-based ecosystem service research works. Nowadays, there are over 18,000 research articles on ecosystem services. It can be concluded that ecosystem topic has got more attention in the scientific community and also the relevance of forest in its ecosystem services are increasing. Therefore, the study proved the existence of growth on ecosystem 


\section{Trends of journal articles publication}

1400

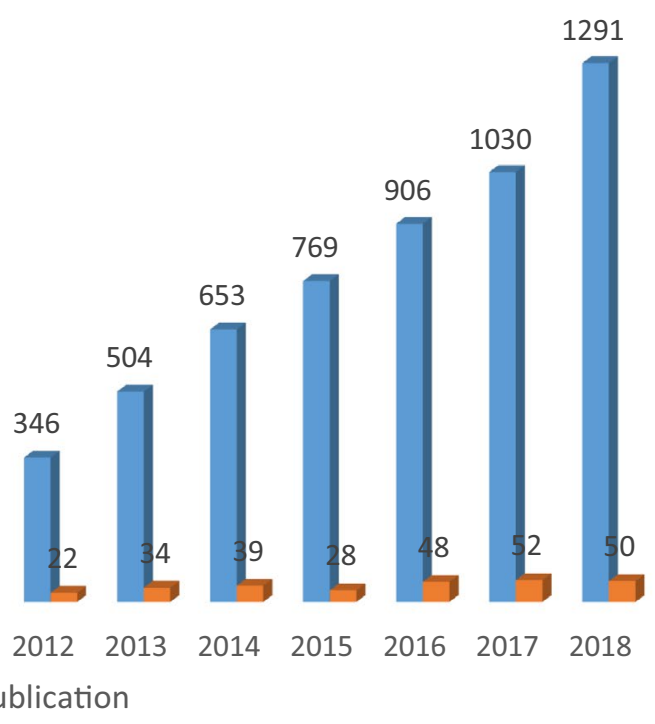

Ecosystem Services $\quad$ Forest Ecosystem Services

Fig. 2 Comparative trends on journal articles published on ecosystem and forest ecosystem services from 2005 to 2018 using science direct database. According to the data source of science direct since 2005 to 2018, more number of articles were published on ecosystem services mainly after the publication of the Millennium Ecosystem Assessment. The publication linked to forest ecosystem services are not that increasing like the ecosystem services research trends. A very small number of articles were produced to map, value and quantify forest based ecosystem services

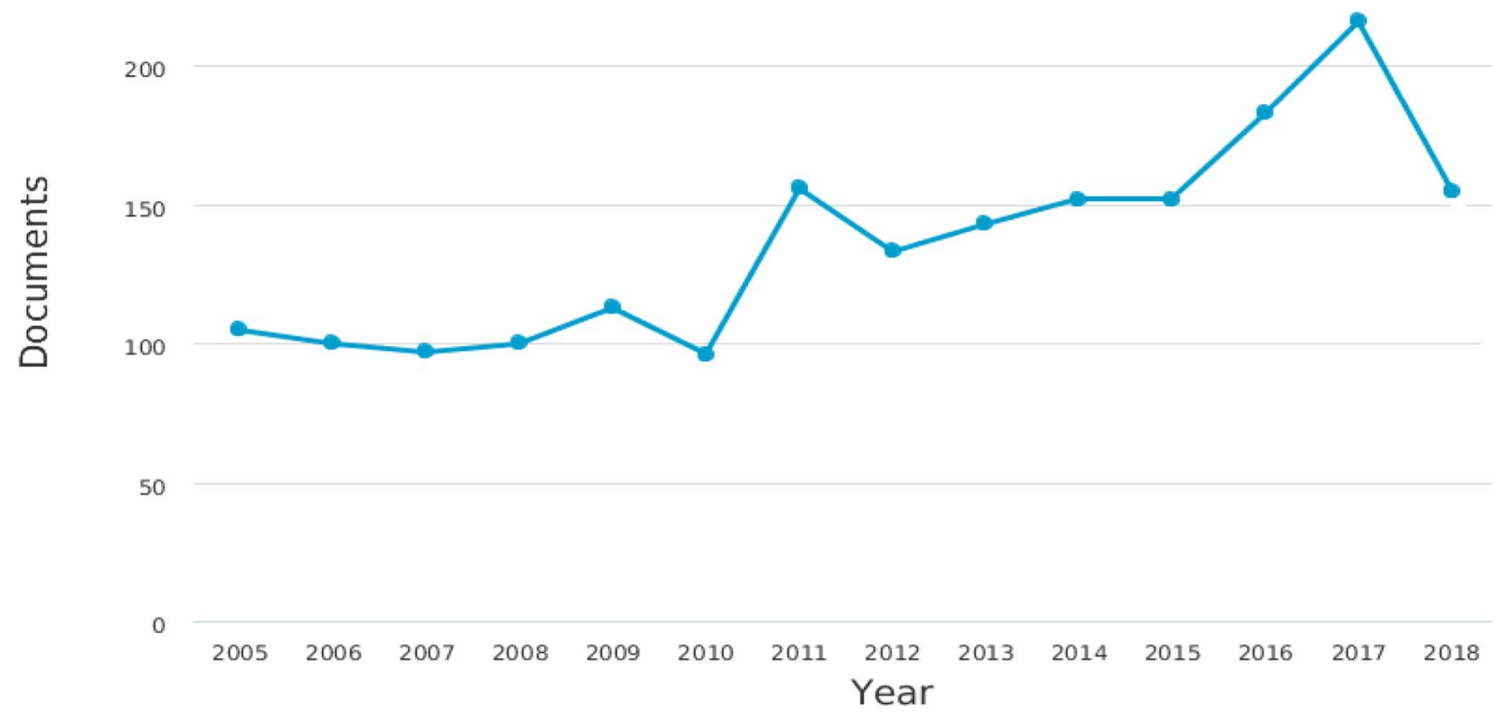

Fig. 3 Trends of forest ecosystem services study from 2005 to 2018 using Scopus database. This figure exclusively explains the trends of forest ecosystem services since 2005 on wards using Scopus as the main data source. It showed that the number of publication is increasing in positive ways up to 2017. However, the last year (2018) had the lower number of publication and it might be linked with the time demands to register the published articles from various journal types in Scopus data base 


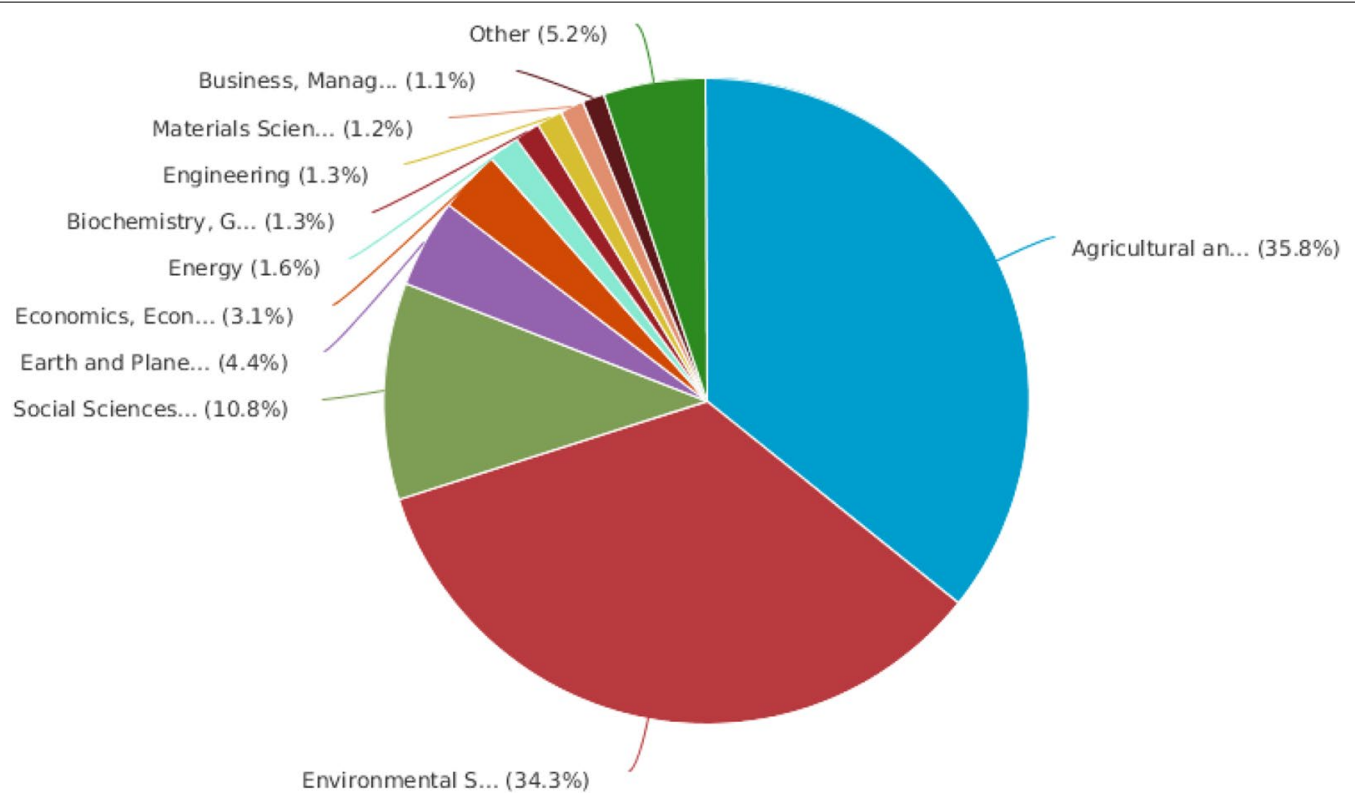

Fig. 4 The percentage of ecosystem service publication based on subject areas. This figure stated authors' background who published articles in relation to ecosystem services. Most of the articles were published from authors with agricultural and biological, and environmental science background

service publication using the sample sources. However, this analysis was not considering articles that are stating ecosystem services but not used the term ecosystem/ forest ecosystem services in their title topic, keywords or abstract.

\section{Distribution and scientific journal production on FES Subject categories}

Note that one article may be simultaneously included in more than one category. Figure 4 shows the subject categories of authors based on Scopus classification from 2005 to 2018. Throughout the whole period analyzed, $35.8 \%$ of the published articles were classified under Agricultural and Biological Sciences. The next which was 34.3\% in Environmental Science, 10.8\% Social Sciences, 4.4\% Earth and Planetary Sciences, and 3.1\% under Economics, Econometrics and Finance. The remaining categories account for less than 3\% of published articles.

Based on principal subject categories under which Scopus classified articles on forest ecosystem services, two subject areas shared about $70 \%$. These were Agricultural and Biological Sciences, and Environmental Science. Similarly, in the reviewed work of Aznar-Sánchez et al. (2018), these two subject areas were dominant and shared more than 60\% of the published articles from 1998 to 2017. This slight variation between these two reviews might be due to variation in data sources and time period of the review covered.
Dobbertin and Nobis (2010) reviewed the publications of 6 journal articles on forests during the 1979-2008 periods. As a result, they mentioned that the titles of forest or forestry publications are increasingly include topics from Natural Sciences but Economic and Social Sciences topics are still underrepresented. Their result showed that social and economic topics are understudied. However, in the work of Aznar-Sánchez et al. (2018), they could observe that there is a relevant presence of Social Sciences in forest ecosystem services but the economic presence is still limited. On this review work, however, the Social Science and Economics, Econometrics and Finance had a relatively better share in forest ecosystem services research. However, other social science like Business, Management and Accounting had weak involvement in the FES studies.

\section{Publication by countries}

Table 2 shows the evolution in the number of articles for FES in the top 10 countries from 2005 to 2018. The United States placed first, followed by, Canada, Germany, China, and the United Kingdom. Compared with AznarSánchez et al. (2018, reviewed work, two countries, South Korea and Finland- which were replaced by Brazil and France were absent in the top ten productive country lists. This variation might be related to the search engine term we used and the sources of the database.

Table 2 also shows the number of articles published on ES and if the number of ES articles were considered, the 
Table 2 The top 10 most productive countries in FES and ES papers (2005 to 2018) from ¥he Scopus database

\begin{tabular}{llrrr}
\hline & Country & Total FES & Total ES & Ratio \\
\hline 1 & United States & 1346 & 6217 & 21.65 \\
2 & Canada & 138 & 1120 & 12.33 \\
3 & Germany & 71 & 2133 & 3.33 \\
4 & China & 68 & 1757 & 3.87 \\
5 & United Kingdom & 58 & 2993 & 1.94 \\
6 & Spain & 45 & 1102 & 4.08 \\
7 & Australia & 38 & 1599 & 2.38 \\
8 & Italy & 36 & 1120 & 3.21 \\
9 & South Korea & 34 & 94 & 36.17 \\
10 & Finland & 29 & 453 & 6.40 \\
\hline
\end{tabular}

USA comes first and South Korea tenth. These countries were also considered to act as the main research drivers in the ecosystem services research, except for Finland and South Korea, which their position was replaced by Spain and Netherlands, respectively. The United Kingdom is the country with the second highest article number next to the USA if we consider its publications on ES and followed by Germany.

Table 2 also shows the percentage of ecosystem services articles which deal with forest ecosystem services per journal \{(FES/ES: number of articles on forest ecosystem services/number of published articles on ecosystem services) $\times 100\}$. The analysis period of each journal begins in 2005 with its publication on FES. The country with the highest ratio was in South Korea of which from the total ecosystem publication, about $36.17 \%$ was on FES. However, this did not imply that South Korea leading others in its publication number rather the small variation between the number of ES and FES publication made the ration highest. The next highest was in the USA, which was $21.65 \%$, but the least was in the United Kingdom (1.94\%).

\section{Publication by journal types}

Figure 5 shows the five journals with the most publications on FES from 2005 to 2018 . The most productive journal in this field was Journal of Forestry, with a total of 106 (7.1\%) articles. Forest Ecology and Management, with a total of 87 (5.8\%) article was the second largest journal. This journal publishes a lower number of articles than the Journal of Forestry, but its SCImago Journal Rank (SJR) index (1.625) is the highest from all journals. According to Aznar-Sánchez et al. (2018), Forest Ecology and Management journal had the first article on FES in 2001 and had the first position after 2005. The third and fourth journals with the largest number of published articles were USDA Forest Service General Technical Report PNW Gtr and USDA Forest Service General Technical Report RMRS Gtr, which equally had 65 (4.4\%) articles. USDA Forest Service General Technical Report PNW Gtr was the most recent publication to join this field of research, and publishing its first article on FES in 2008. Despite this, it takes the lead in the number of articles published in the most recent period, 2011 and 2016, but has the lowest SJR index (0.128). Forest Policy and Economics were

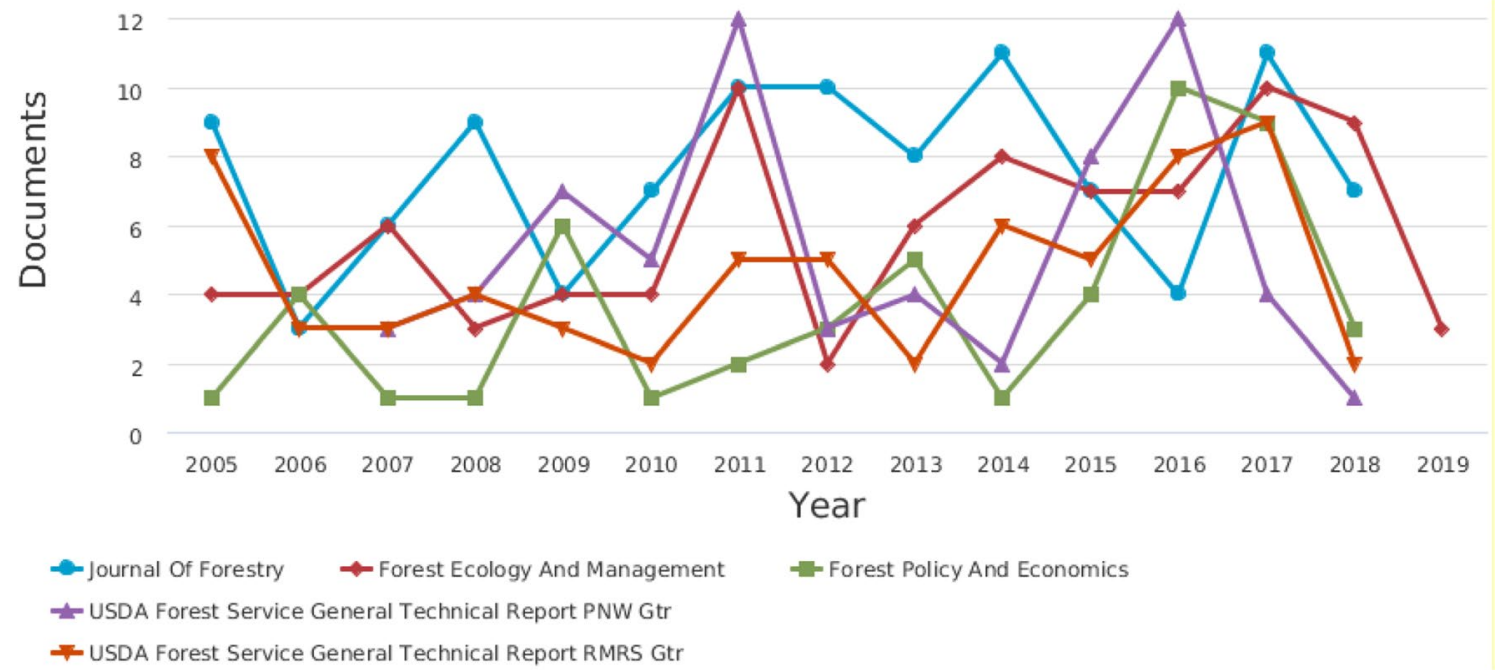

Fig. 5 The first five journal types that published research works on FES. The issues on ecosystem services were published in diverse journal types. Among them the first five journal lists that had a large number of research publication on ecosystem services were listed. The concept of ecosystem services motivated to launch a new journal of ecosystem services by known publishers to publish research on ecosystem services 


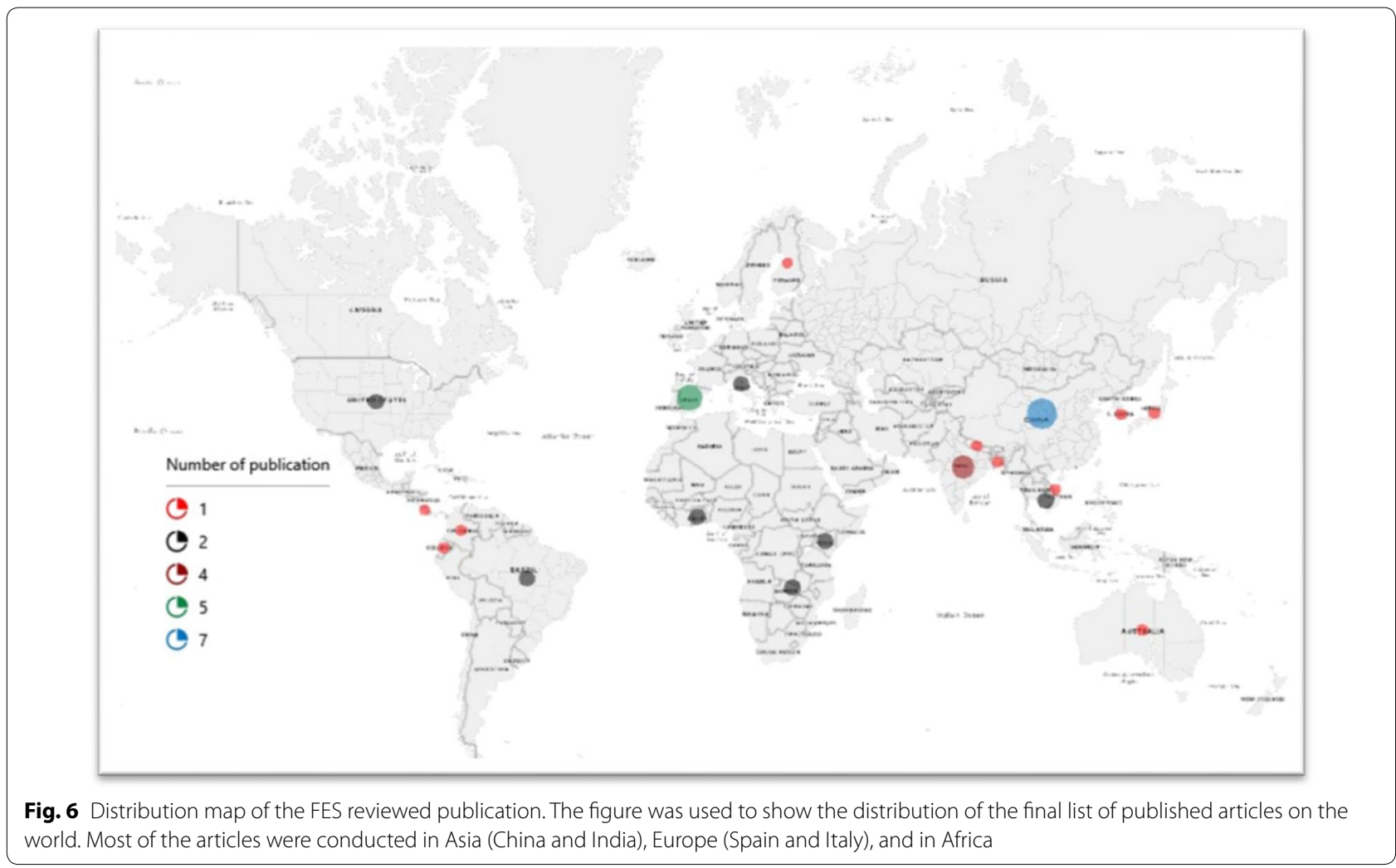

in fifth place with 51(3.4\%) articles. These five journals comprise only $25.12 \%$ of the total number of articles published because scientific articles on FES are published in a very wide range of journals.

The Journal of Ecosystem Services has low rank based on the number of publication, which was 30 articles $(2.0 \%)$ and had the eighth place. It is the most recent publication that joins this field of research and published its first article on FES in 2013 (Aznar-Sánchez et al. 2018). Despite this, it takes the lead in the number of articles published and has the highest SJR index (1.743). It should be noted that the journals with the highest number of articles on FES are of the highest quality.

\section{The reviewed publications on FES}

\section{Overview of FES types and their distribution}

As marked in Fig. 6, the 41 studies included were conducted in six continents; Asia (18 studies), Europe (9 studies), Africa (6 studies), Australia (1 study), North America (2 studies) and South America (5 studies). The study represented 20 countries and a single study in Europe cover 26 countries, which was a study at a regional scale. The selected studies had cover eight countries from Asia, five countries from America, three countries from Europe and Africa each, and one from Australia. The study covered small number of world countries and were not enough to cover the forest resources of the continents. For instance, at country level, China and Spain had the largest number of publication, which each has seven and five published articles, respectively. Thus, quantitative inference based on the existed results were less sound.

Figure 7 shows the list of eighteen journal types where the reviewed articles were published. The journal with the most publication number was Ecosystem Services that published 13 papers out of the 41 reviewed articles. The next was Forest Policy and Economics that had a publication of four papers. Two journals i.e. Ecological Indicators and Land Use Policy each had three publications. From the remaining 14 journal types, four journals each had two publications and the rest 10 journals had one publication each. The number of ecosystem services investigated is different across the reviewed articles, ranging from a minimum of one to a maximum of 13 in a single paper.

From the ecosystem services included in the sample, $85.4 \%$ and $82.9 \%$ were regulatory and provisioning ecosystem services i.e. were 35 and 34 publications, respectively. Twenty reviewed (48.8\%) papers dealt with cultural services, and 18 (37.5\%) papers deal with supporting services. The studies differ in their spatial scope, time of the 


\section{List of journals published the selected articles}

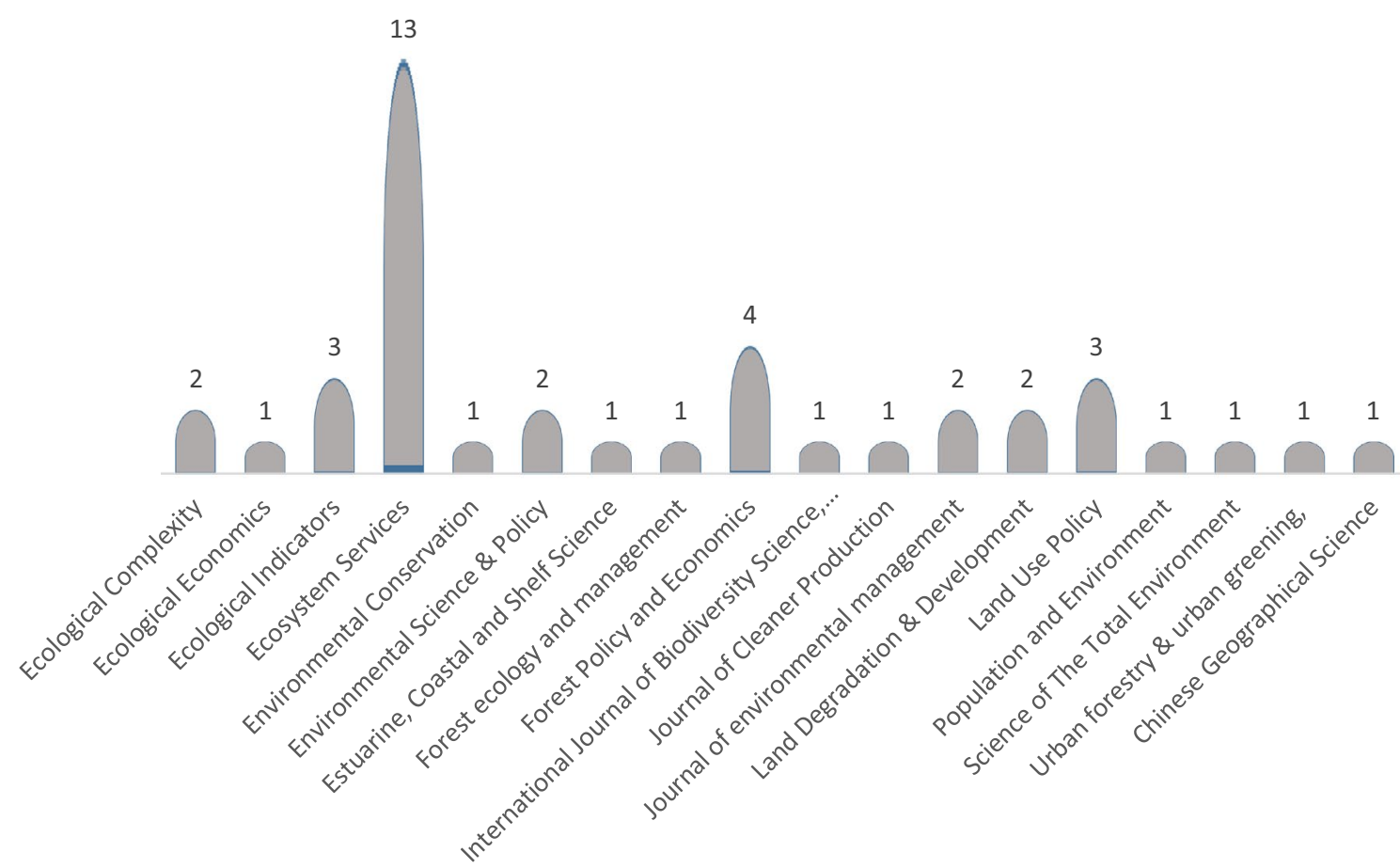

Fig. 7 List of journals that published selected publication used for further analysis. It includes journal types that published the articles selected for final analysis using the selection criteria. The total number was 18 journal types and 10 of them got published only one article and one journal (ecosystem services) alone published 13 articles out of 41

study, the ecosystem services assessed and the methodology used.

The 41 selected articles deal with mapping, valuation, and quantification/qualification of FES and in general cover about 243 FES indicators. Figure 8 listed the most common ES addressed in the reviewed literature. The most common services investigated from provisioning ES were timber production and water provision, which had equally 46.3\%; carbon sequestration (65.9\%) and erosion control (34.1\%) from regulating ES; recreation (46.3\%) and, tourism, education and research (14.6\%) from cultural ecosystem services and soil conservation (22\%) from supporting ecosystem services. However, cultural and supporting ecosystem services were most underresearched ecosystem service category (Howe et al. 2014; Cruz-garcia et al. 2016). This has been common in the literature (Defries et al. 2004; Rodriguez et al. 2006) and the reason could be one or more of the following. These services are not well defined and understood like provisioning or regulating services (Crossman et al. 2013), and the methodology might not be easy to study and/or measure the given ecosystem services.

Based on the mode of FES assessment, 22 publications $(53.7 \%)$ of the reviewed paper used economic valuation,
8 publications (19.5\%) of FES mapping, and 10 publications (24.4\%) of FES quantification/qualification. Publications on economic valuation was higher than mapping and quantification/qualification of FES. Two publication (Joshi and Negi 2011; Duc et al. 2018) combined two modes of FES assessments, that is 'quantification/qualification' and valuation, and 'mapping' and 'valuation' and one publication (Escobedo et al. 2015) was undefined. However, they ended up with more focus and detail investigation on one of the assessment mode. For each reviewed paper, the following basic information was summarized: authors and location; methods employed to assess ecological functions; methods employed for estimating monetary values; estimates for the total FES; and estimates per hectare (Tables 3, 4, 5, 6, 7 and 8).

\section{Methodological approaches used by the selected papers}

Provisioning FES Provisioning ecosystem service category mainly includes Food, Fiber, Genetic resources, Freshwater, Ornamental resources, Bio-chemicals, Natural Medicines, etc. (MEA 2005). From these ecosystem services, the most covered in the reviewed articles were water yields and timber production. According to Table 3, each author used a distinct method of water yield valua- 
a Most studied from Regulating ES

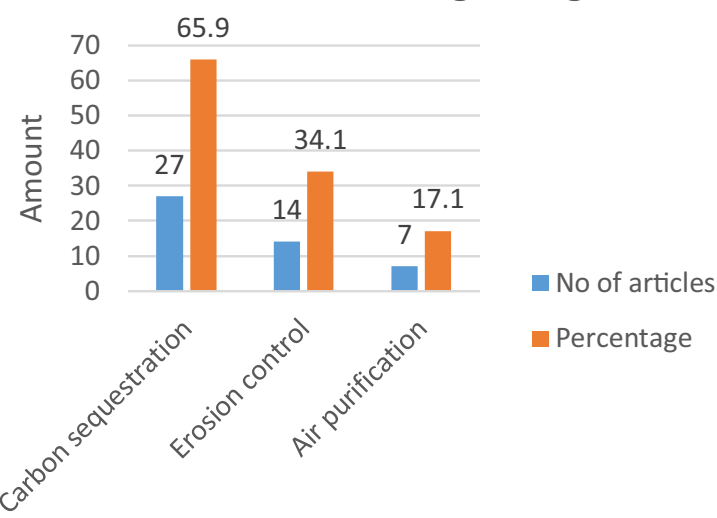

Indicators

\section{c Most studied from cultural ES}

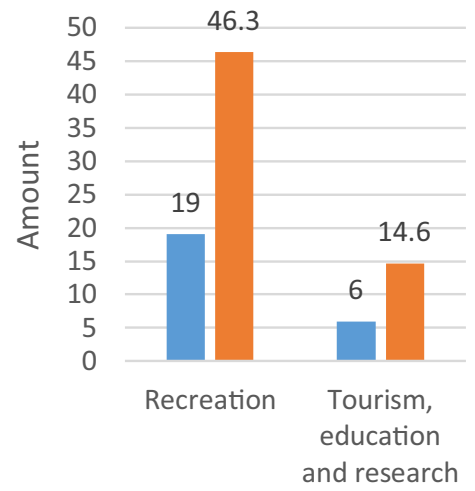

Indicators

\section{b Most studied from provisioning services}

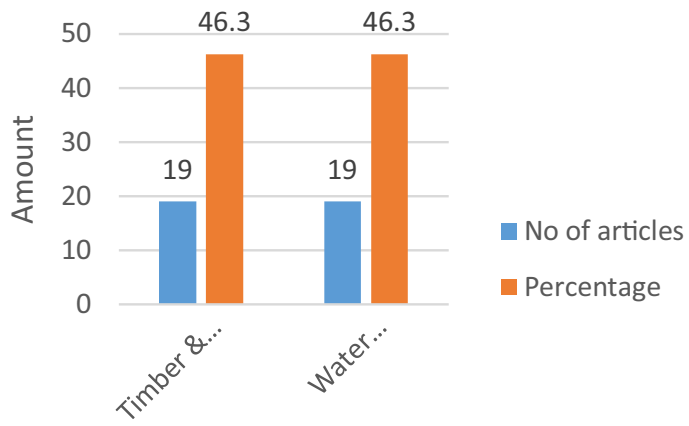

Indicators

\section{d Most studied from supporting ES}

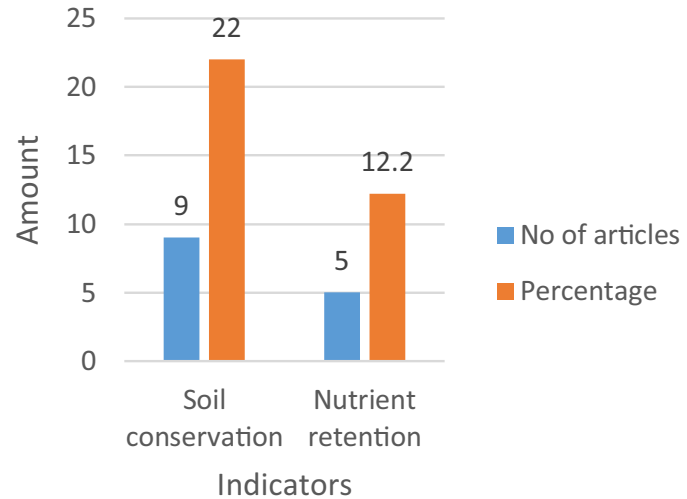

Fig. 8 Most common FES investigated from the selected reviewed literature. Using the final list of articles, the most common forest ecosystem services well studied were described. Majority of the work concentrated on regulating (carbon sequestration, erosion control), provisioning services (timber production and water supply) and recreation from cultural ecosystem category

tion. This implies that the valuation techniques for water yield estimation was diverse. In contrast, the economic valuation techniques for timber productions were related to market prices. However, the total values and the per hectare and per year estimate were local dependent, which was higher in most developing countries and lower in less developing countries. For instance, in Kenya by

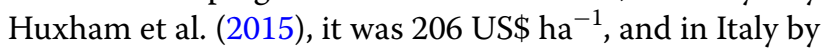
Häyhä et al. (2015), estimated $218 £$ ha $^{-1}$ year $^{-1}$ (248.084 US\$). Therefore, the economic value of timber was local dependent.

Regulatory FES This category includes air quality regulation, climate regulation, water regulation, erosion regulation, disease regulation, pest regulation and polli- nation (MEA 2005). Among them, from the 24 reviewed literature, most of them addressed climate regulation and erosion regulation. Through photosynthesis, carbon is stored in forests and is a function of forest productivity (Brockerhoff et al. 2017). Based on Table 5, the economic valuation of carbon sequestration was diverse in its types. The volume of carbon sequestered by forests was commonly estimated based on market/carbon market price (Ninan and Inoue 2013a; Morri et al. 2014; Huxham et al. 2015; Ninan and Kontoleon 2016; Kibria et al. 2017; Wang et al. 2018). Morri et al. (2014) used $20 £ / \mathrm{tCo}_{2}$ in Italy and Huxham et al. (2015) in Kenya used $10 \mathrm{US} \$ / \mathrm{tCo}_{2}$. Few studies used carbon tax method of economic valuation for carbon sequestration. These were Kibria et al. (2017) used carbon tax using InVEST model with a value 
Table 3 Reviewed studies dealing with water yield including the methodology and monetary value

\begin{tabular}{|c|c|c|c|c|}
\hline No & Authors and study site & Valuation methods & Estimate per hectare year ${ }^{-1}$ & Total FES \\
\hline 1 & Vogl et al. (2016), India (Baspa II) & InVEST water yield model & - & 1190 mm year ${ }^{-1}$ \\
\hline 2 & $\begin{array}{l}\text { Vogl et al. (2016), India (Ghanvi I } \\
\text { watershed) }\end{array}$ & InVEST water yield model & - & $1598 \mathrm{~mm}$ year $^{-1}$ \\
\hline 3 & Duc et al. (2018), Vietnam & Residual valuation model & 68.42 million US\$ year $^{-1}$ & 161.5 million US\$ year ${ }^{-1}$ \\
\hline 4 & Ninan and Inoue (2013a) in Japan & Alternative cost & 1.385 billion US\$ year $^{-1}$ & - \\
\hline 5 & Kibria et al. (2017), Cambodia & Rainfall storage method & 399 US\$/ha year ${ }^{-1}$ & 22.21 million US\$/ha year ${ }^{-1}$ \\
\hline 6 & Li et al. (2017), China & $\begin{array}{l}\text { Avoided cost of detention of a unit } \\
\text { of water }\end{array}$ & $147.75 \times 10^{9} \mathrm{~m}^{3}$ year $^{-1}$ & - \\
\hline 7 & Mamat et al. (2018), in China & $\begin{array}{l}\text { Adopt the benefit transfer method of } \\
\text { Costanza et al. (1997) and Xie et al. } \\
\text { (2008) }\end{array}$ & $11,877.67$ US\$ ha ${ }^{-1}$ year $^{-1}$ & - \\
\hline 8 & Gaodi et al. (2010), China & $\begin{array}{l}\text { Replacement price method of water } \\
\text { resource }\end{array}$ & $331.92 \times 10^{6} ¥$ in 2004 & - \\
\hline 9 & Biao et al. (2008), in Beijing & $\begin{array}{l}\text { Adopt based on monthly precipita- } \\
\text { tion and surface runoff (Li and } \\
\text { Chen 1997) }\end{array}$ & $287 \times 10^{6} \mathrm{~m}^{3}$ of fresh water & - \\
\hline 10 & Morri et al. (2014) in Marecchia (Italy) & Direct market price & 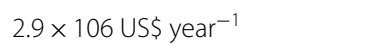 & \\
\hline 11 & Morri et al. (2014) in Foglia (Italy) & Direct market price & $3.1 \times 106$ US\$ year $^{-1}$ & \\
\hline 12 & Beier et al. (2017) & $\begin{array}{l}\text { using an estimate of avoided treat- } \\
\text { ment (i.e., liming) costs }\end{array}$ & $\begin{array}{l}\text { On average from } \$ 49.98 \mathrm{ha}^{-1} \text { to } \\
\$ 7.22 \mathrm{ha}^{-1}\end{array}$ & - \\
\hline 13 & Delphin et al. (2016) & InVEST model & Mean of $1290 \times 10^{3} \mathrm{~m}^{3}$ in 2003 & - \\
\hline 14 & Bernard et al. (2009) & Avoided cost method & US\$169,470 year ${ }^{-1}$ & - \\
\hline
\end{tabular}

Table 4 Reviewed studies dealing with timber production including its methodology and monetary value

\begin{tabular}{|c|c|c|c|c|}
\hline No & Authors and study site & Valuation methods & Estimate per hectare/year & Total FES \\
\hline 1 & Joshi and Negi (2011), India (Oak forest) & $\begin{array}{l}\text { Based on the prevailing cost paid for minor } \\
\text { timber }\end{array}$ & 26,509 RS year $^{-1}$ (8 tons/head year ${ }^{-1}$ ) & - \\
\hline 2 & Joshi and Negi (2011), India (Pine forest) & $\begin{array}{l}\text { Based on the prevailing cost paid } \\
\text { for minor timber }\end{array}$ & $11,096 \mathrm{RS}$. year ${ }^{-1}$ (4 tons/head year ${ }^{-1}$ ) & - \\
\hline 3 & Kibria et al. (2017), Cambodia & Direct market valuation & $6.37 \mathrm{~m}^{3}$ year $^{-1}$ & 350 US\$ \\
\hline 4 & Ojea et al. (2012), sustainable harvest & Stumpage price & $18.78 £ \mathrm{ha}^{-1}$ year $^{-1}$ & - \\
\hline 5 & Ojea et al. (2012), unsustainable harvest & Stumpage price & $56.28 £$ ha $^{-1}$ year $^{-1}$ & - \\
\hline 6 & Uddin et al. (2013) & Direct valuation method & 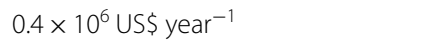 & - \\
\hline 7 & Huxham et al. (2015), Kenya & $\begin{array}{l}\text { Market price (deduct harvest and production } \\
\text { cost) }\end{array}$ & 206 US\$ ha ${ }^{-1}$ & - \\
\hline 8 & Häyhä et al. (2015), Italy & Volume of harvest & $89,500 \mathrm{~m}^{3}$ year $^{-1}$ & - \\
\hline 9 & Häyhä et al. (2015), Italy & The market value of timber & $218 \pm$ ha $^{-1}$ year $^{-1}$ & $8,693,135 £$ year $^{-1}$ \\
\hline 10 & Gaodi et al. (2010). 2010, China & Market price method (for timber) & $391.16 \times 106 \neq($ in 2004) & - \\
\hline 11 & Kanungwe et al. (2013), Zambia & Cash income reported by households & 1834KR year ${ }^{-1 a}$ & - \\
\hline 12 & Alarcon et al. (2015) & InVEST model & US\$ 65.4 ha $^{-1}$ year $^{-1}$ & - \\
\hline 13 & Verkerk et al. (2014) & $\begin{array}{l}\text { Round wood prices (industrial- and fuel- } \\
\text { wood) }\end{array}$ & 73 million $\mathrm{m}^{3}$ year $^{-1}$ & - \\
\hline 14 & Delphin et al. (2016) & Using InVEST model & Mean of 109.5 tons in 2003 & - \\
\hline 15 & Tilahun et al. (2016) & Stumpage value & $\begin{array}{l}\text { The volume of } 279.59 \mathrm{~m}^{3} \mathrm{ha}^{-1} \text { worth } \\
\text { of } 131.22 \$ \mathrm{ha}^{-1}\end{array}$ & - \\
\hline 16 & Mutoko et al. (2015) & Willingness to pay & 6 US\$ ha ${ }^{-1}$ year $^{-1}$ & 107,000 US\$ \\
\hline
\end{tabular}

\footnotetext{
a Include all provisioning services collected by households like timber, food, charcoal, thatching materials
} 
Table 5 Reviewed studies dealing with carbon sequestration including its methodology and monetary value

\begin{tabular}{|c|c|c|c|c|}
\hline No & Authors and study site & Valuation methods & Estimate per hectare year ${ }^{-1}$ & Total FES \\
\hline 1 & Morri et al. (2014) in Marecchia, Italy & Carbon market price $\left(20 £ / \mathrm{tCO}_{2}\right)$ & - & $7.32 \times 10^{6} £$ year $^{-1}$ \\
\hline 2 & Morri et al. (2014) in Foglia, Italy & Carbon market price $\left(20 £ / \mathrm{tCO}_{2}\right)$ & - & $6.60 \times 10^{6} £$ year $^{-1}$ \\
\hline 3 & Duc et al. (2018), Vietnam & The social cost of carbon & 13,396 million US\$ year ${ }^{-1}$ & - \\
\hline 4 & Ninan and Kontoleon (2016) in India & Market price and damage cost & 37,934 tons year $^{-1}$ & - \\
\hline 5 & Ninan and Inoue (2013a) in Japan & Market price & $2,044,893.846$ US\$ year $^{-1}$ & - \\
\hline 6 & Kibria et al. (2017), Cambodia & Carbon tax using InVEST model & 141 US\$ ha ${ }^{-1}$ year $^{-1}$ & $7.78 \times 10^{6}$ US $\$$ year $^{-1}$ \\
\hline 7 & Li et al. (2017) in China & Carbon tax law method & $3.41 \times 10^{7}$ ton year $^{-1}$ & \\
\hline 8 & Huxham et al. (2015), Kenya & $\begin{array}{l}\text { Based on current market value(10US\$/ } \\
{\mathrm{t}\left(\mathrm{O}_{2}\right)}^{2}\end{array}$ & 251 US\$ ha ${ }^{-1}$ & - \\
\hline 9 & Häyhä et al. (2015) in Italy & $\begin{array}{l}\text { Amount of carbon sequestered by } \\
\text { biomass }\end{array}$ & 201,350 ton $\mathrm{CO}_{2}$ & - \\
\hline 10 & Häyhä et al. (2015) in Italy & Carbon emission permit price & $76 £$ ha $^{-1}$ year $^{-1}$ & $3,020,246 £ y^{-1}$ \\
\hline 11 & Wang et al. (2018), China & Market price approach & 73 US\$ ha ${ }^{-1}$ year $^{-1}$ & 12,738 US\$ (in 2015) \\
\hline 12 & Mamat et al. (2018), Chna & $\begin{array}{l}\text { Adopt a benefit transfer method of Cos- } \\
\text { tanza et al. (1997), Xie et al. (2008) }\end{array}$ & $12,545.66$ US\$ ha $^{-1}$ year $^{-1}$ & - \\
\hline 13 & Gaodi et al. (2010), China & Afforestation cost method & - & $3532.49 \times 10^{6} ¥($ in 2004$)$ \\
\hline 14 & Escobedo et al. (2015) & Tree $C$ kg per analysis unit & - & 76,500 tons \\
\hline 15 & Delphin et al. (2016) & Using InVEST model & 196 mean carbon storage $\left(\mathrm{Mg} \mathrm{ha}^{-1}\right)$ & - \\
\hline 16 & Tilahun et al. (2016) & Stumpage value & $\begin{array}{l}1229.93 \text { tCO2e ha }{ }^{-1} \text { worth of } 7256.78 \\
\$ \text { ha }^{-1}\end{array}$ & - \\
\hline
\end{tabular}

Table 6 Reviewed studies dealing with erosion regulation/sediment yields including its methodology and monetary value

\begin{tabular}{lllll}
\hline No & Authors and study site & Valuation methods & Estimate per hectare year & Total FES \\
\hline 1 & Morri et al. (2014), in Foglia, Italy & Avoided cost of restoring soil & $1.79 \times 10^{6} £$ year \\
2 & Morri et al. (2014), in Maracchia, Italy & Avoided cost of restoring soil & $1.72 \times 10^{6} £$ year & -1 \\
3 & Vogl et al. (2016), in Bashpa II, India & Using RUSEL by InVEST model & 630,124 ton year $^{-1}$ & - \\
4 & Vogl et al. (2016), in Ghanvi watershed, India & Using RUSEL by InVEST model & 28,335 ton year $^{-1}$ & - \\
5 & Duc et al. (2018) & Replacement cost method & 1 million US\$ year & - \\
6 & Ninan and Inoue (2013a), Japan & Hedonic pricing & $310,311.746$ US\$ year $^{-1}$ & - \\
7 & Ninan and Inoue (2013a), Japan & Opportunity cost & $31,122.21$ US\$ year $^{-1}$ & - \\
8 & Kibria et al. (2017), Cambodia & Cost of per ton of sediment removal & 32 US\$ ha $^{-1}$ year $^{-1}$ & 1.76 million $^{-}$ \\
\hline
\end{tabular}

Table 7 Reviewed studies dealing with soil conservation/formation including its methodology and monetary value

\begin{tabular}{|c|c|c|c|c|}
\hline No & Authors and study site & Valuation methods & Estimate per hectare year ${ }^{-1}$ & Total FES \\
\hline 1 & Ninan and Kontoleon (2016), India & Hedonic pricing & - & 132.33 million US\$ year $^{-1}$ \\
\hline 2 & Ninan and Kontoleon (2016), India & Opportunity cost & - & 0.07 million US\$ year ${ }^{-1}$ \\
\hline 3 & Kibria et al. (2017), Cambodia & Using nutrient cycling formula & 170 US\$ year $^{-1}$ & 9.47 million US\$ \\
\hline 4 & Li et al. (2017), in China & $\begin{array}{l}\text { Calculating the quantity of nutrients and fertiliz- } \\
\text { ers kept by the forest }\end{array}$ & $6.56 \times 10^{8}$ ton year $^{-1}$ & - \\
\hline 5 & Mamat et al. (2018) in China & Adopt a benefit transfer of Costanza et al. (1997) & $11,674.62$ US\$ ha year $^{-1}$ & - \\
\hline 6 & Gaodi et al. (2010), China & Replacement price method of fertilizer & $351.45 \times 10^{6} ¥($ in 2004$)$ & - \\
\hline 7 & Gaodi et al. (2010), China & Replacement price method of organic manure & $728.67 \times 10^{6} ¥($ in 2004$)$ & - \\
\hline 8 & Niu et al. (2012) & Market valuation method & - & 84.33 billion $¥$ \\
\hline 9 & Sheng et al. (2017) & Using economic valuation techniques & $28 ¥ \mathrm{ha}^{-1}$ year $^{-1}$ & - \\
\hline 10 & Ditt et al. (2010) & Using a universal soil loss equation & - & 737,744 tons \\
\hline
\end{tabular}


Table 8 Reviewed studies dealing with recreation including its methodology and monetary value

\begin{tabular}{|c|c|c|c|c|}
\hline No & Authors and study site & Valuation methods & Estimate per hectare year ${ }^{-1}$ & Total FES \\
\hline 1 & Ninan and Kontoleon (2016), India & Travel cost and benefit transfer approach & - & 0.37 million US\$ year ${ }^{-1}$ \\
\hline 2 & Ninan and Inoue (2013a), Japan & Willingness to pay & 11.72-27.04 million US\$ & \\
\hline 3 & Kibria et al. (2017), Cambodia & $\begin{array}{l}\text { A number of tourists multiplied by the } \\
\text { average price of tourist paid per year. }\end{array}$ & 0.37 US\$ ha ${ }^{-1}$ year $^{-1}$ & 0.02 million US\$ ha $^{-1}$ year $^{-1}$ \\
\hline 4 & Uddin et al. (2013), Bangladesh & Direct market valuation & 42,000 US\$ year $^{-1}$ & - \\
\hline 5 & Häyhä et al. (2015), Italy & $\begin{array}{l}\text { Number of tourists: areas with landscape } \\
\text { value }\end{array}$ & - & $1,094,866$ person $\mathrm{y}^{-1}$ \\
\hline 6 & Häyhä et al. (2015), Italy & Number of hunters & - & 498 person year $^{-1}$ \\
\hline 7 & Häyhä et al. (2015), Italy & Tourists' willingness to pay & $77 £$ ha $^{-1}$ year $^{-1}$ & $3,090,281 £$ year $^{-1}$ \\
\hline 8 & Häyhä et al. (2015), Italy & $\begin{array}{l}\text { Cost of hunting(permit, license and insur- } \\
\text { ance) }\end{array}$ & $10 £$ ha $^{-1}$ year $^{-1}$ & $385,425 £$ year $^{-1}$ \\
\hline 9 & Mamat et al. (2018), in China & $\begin{array}{l}\text { Adopt benefit transfer value of Costanza } \\
\text { et al. (1997) and Xie et al. (2008) }\end{array}$ & 6040.36 US\$ ha $^{-1}$ year $^{-1}$ & - \\
\hline 10 & Gaodi et al. (2010), China & $\begin{array}{l}\text { Benefit transfer method based on tourism } \\
\text { income of Beijing }\end{array}$ & $415.72 \times 10^{6} ¥($ in 2004$)$ & - \\
\hline 11 & Bernard et al. (2009) & Market analysis & $1,250,000$ US\$ year ${ }^{-1}$ & 625,000 million US\$ year ${ }^{-1}$ \\
\hline 12 & Mutoko et al. (2015) & Willingness to pay & 179 US\$ ha hear $^{-1}$ & $3,185,000$ US\$ \\
\hline 13 & Birch et al. (2014) & Using an entrance survey & $\begin{array}{l}\text { An average income of } \\
\$ 1600 \text { year }^{-1} \text { per community } \\
\text { forest user groups }\end{array}$ & $\$ 8000$ year $^{-1}$ \\
\hline
\end{tabular}

of 141US\$ hectare ${ }^{-1}$ year $^{-1}$ in Cambodia, Li et al. (2017) used carbon tax law method with estimation value of $3.41 \times 10^{7}$ ton $^{-1}$ year $^{-1}$ in China and Delphin et al. (2016) in the USA. There were two other case studies (Gaodi et al. 2010; Duc et al. 2018) which used social and afforestation costs for climate regulation ecosystem services. In addition, the estimated monetary value per hectare basis for the same ecosystem services was vary. For instance, Morri et al. study in Italy at two watersheds (Marecchia and Foglia) estimates the total ES value of $7.32 \times 10^{6} £$ year $^{-1}$ and $6.60 \times 10^{6} £$ year $^{-1}$ respectively (Morri et al. 2014). According to D'Amato et al. (2016), for hydrological estimates in China, the monetary value was range from a few dollars to thousands. The next regulatory ecosystem services that had economic and biophysical estimation was erosion regulation of forests. Table 6 shows each author used different techniques of estimating soil erosion in their study. The valuation and monetary estimation techniques were also varied across different studies. However, air quality regulation of forest was studied in South Korea by Song et al. (2016), and the finding showed that forests can sequester about $8.6 \mathrm{~kg} \mathrm{SO}_{2}$ and $16.8 \mathrm{~kg} \mathrm{NO}_{2} \mathrm{ha}^{-1}$. In 2011, the whole forest was sequestered of 52,150 and 93,254 tons of $\mathrm{SO}_{2}$ and $\mathrm{NO}_{2}$, respectively.

FES benefits that lack direct market valuation could be valued in monetary terms using non-market valuation methods like cost-based methods (i.e. avoided cost or damage) which was particularly suitable for approaching regulating services (de Groot et al. 2012). In addition, the benefit transfer, opportunity cost, willingness to pay and replacement price methods were commonly used. These methods help to estimate the monetary value of local ecological functions performed by using replacement price method. It helps to measure the cost of replacing the ecosystem services through other means. For example, the value of forest for soil conservation and soil formation could be estimated using the replacement price method of fertilizers and organic manure. For FES where the use values were not clear or non-use values were dominant, other methods like hedonic pricing, willingness to pay and travel cost could be employed.

Supporting FES Supporting ecosystem services includes soil formation, photosynthesis, primary production, nutrient cycling and water cycling (MEA 2005). From the 24 reviewed literature result, the most studied ES were soil formation and nutrient cycling ecosystem service. According to Table 7, soil formation was included in six studies and was typically based on replacement price method of the price of fertilizer, where the values estimated was $351.45 \times 10^{6} ¥$ and organic manure from the decomposition of litter had a value estimate of $728.67 \times 10^{6} ¥$ per year in China in 2004 . The other estimation method was hedonic pricing, opportunity cost and benefit transfer of Costanza et al. (1997). The value of FES was therefore high in some areas. For instance, the studies of Kibria et al. (2017) in India and Ninan and Kon- 
toleon (2016) in Cambodia proved the high cost of FES, which might be related with the land price.

Cultural FES Cultural services include recreation, education, aesthetic, and sense of place, cultural heritage, spiritual and religious, and inspirational services. These services were the nonmaterial benefits which people can obtain from ecosystems through a spiritual enrichment, cognitive development, reflection, recreation, and aesthetic experiences (MEA 2005). The case study covers section of the cultural ecosystem services, mainly recreation, and tourism, education and research. According to Chan et al. (2012), the possible reason for the absence of most cultural ecosystem services is lack of attention on the non-monetary valuation of ecosystem services. Similarly, the result of this meta-analysis and systematic work showed that cultural ecosystem services were less valued and mapped ecosystem services except for recreation ecosystem services. Another study by Lara-Pulido et al. (2018) finding, cultural ecosystem services was less addressed than regulatory and provisioning services as it has a lower value than other ecosystem services. Moreover, (Milcu et al. 2013) noted that cultural ecosystem services are understudied because of two factors. First, cultural ecosystem services are not emphasized on the whole range of cultural ecosystem services rather on specific parts. Secondly, it is considered as a complementary rather than being leading incentive for decision making.

Table 8 shows the recreation services from the 24 reviewed articles. The methodology used includes benefit transfer, willingness to pay, cost method (travel cost and cost of hunting) and the direct valuation method. As a result, there was a large variation of the monetary values reported. However, recreational ecosystem service was generally valued highly in high income countries (such as Italy and Japan) than low-income countries (e.g. India and Cambodia).

In sum, Tables 3, 4, 5, 6, 7 and 8 infers that there was a great variation in types of ES indicators, economic valuation methods, and reference prices between studies. The reviewed literature employed the market price method (direct market price, stumpage price, and market valuation) and cost methods (avoided cost, opportunity cost, travel cost, replacement cost, cost of removal, social cost) to produce a general approximation of the economic value of water yield and timber production from provisioning, and carbon sequestration and soil erosion control/sediment yields from regulating FES. Benefit transfer methods were more used in cultural FES for economic valuation of recreation service. Further, only a limited number of studies provided a monetary value of the specific ES per unit of area and most of the studies did not provide the size of the forest area used in the study.
Researchers lack consistency in their use of terminology. For instance, some discuss 'carbon sequestration', 'maintenance of favorable climate' or 'climate mitigation'. Other researchers were used the term ' $\mathrm{CO}_{2}$ sequestration'. Some of them provided the total economic value of the ES, however, drawing comparisons and inferences using total ES values were less worthy since the size of the total area used for the investigation was varied across studies.

The studies used different currency types and conducted at varied years. Thus, a simple conversion of the monetary values to international currency might not consider the rate of inflation. In addition, most of the difficulty was related to the different methodological approaches used by the studies. Portman (2013) conducted a critical review on challenges to implement ES in the real world and finally the author concluded two challenges. These were the challenge to mainstreaming the ES concept into policy-making institution and challenge of the assessment methods.

Furthermore, there were papers for example (Zhang et al. 2010; Uddin et al. 2013; Häyhä et al. 2015; Huxham et al. 2015) which did not define well the ecosystem services under investigation, its category, and in some of the reviewed articles, two or more services with different outputs were jointly valued. These challenges had obstruct from making a comparative analysis between different case studies. Therefore, Zhang et al. (2010) recommend first to adopt a unified definition of ecosystem services and to use only standardized methodologies for valuing ecosystem services.

\section{Trends of FES studies in Ethiopia}

In Ethiopia, the amount of publication included both in Scopus and science direct databases were small compared to the amount and diversity of resources we have had. Using the search engine of "ecosystem services" AND "Ethiopia", 107 and 48 publication was found from Scopus and science direct databases, respectively. From these number, five and two papers were reviewed papers from Scopus and science direct databases, respectively. By using the more specific search engine, which was "forest ecosystem services" AND "Ethiopia", the amount of publication was too small, i.e. two and one from the two data sources. This showed that the amount of publication on FES case studies was too small, almost nil, and the existed studies cover ecosystem services at watershed/ landscape level. Therefore, more efforts are needed from scholars of the area to produce a scientific publication on both FES and ES in Ethiopia (see Table 1). 


\section{Conclusion}

The number of publication on ES has increased, however, the FES has shown no remarkable progress in its publication size. Mainly after 2010, there is an increment in the amount of publication on ES. This indicates that both ES has become an increasingly important research area at the global level. They have provided much insight into how to ensure that ecosystem service research is scientifically vigorous and reliable and also conveys a clear message to decision makers.

Based on the review work, the amount and coverage of FES studies available in English in peer-reviewed journals were too small, had limited coverage of FES, and only limited countries have available forest value estimates. From the various FES, water yield and timber production from provisioning; climate change regulation and erosion control from regulating ecosystem services were the most common services addressed by most case studies. However, other basic ecosystem services from forest resources lack attention from the scientific community. Thus, most of the existed research work focus on provisioning, regulatory and cultural services that had a relatively well-developed methodology. Therefore, unlike the forest ecosystem services discussed above, other services, such as pollination, genetic resources and gen poll protection, regulation of pests and human disease, the forest's aesthetic values, waste treatment, environmental purification, and disease regulation, have received less attention in the scientific community due to lack of data, challenges in estimating their value, and lack of welldesigned methods, among other things. There is a need for more information on these neglected forest ecosystem services in order to know the dynamic nature of FES and how local situation impacting the given service types.

Most of the studies used either biophysical and or/economic valuation methods to estimate the given ecosystem services using per hectare per year basis. They have investigated ecosystem services per unit area per year. However, based on this review work, it was not possible to draw a conclusion on the effect of the methodology used on the monetary estimate of the given ecosystem services. This was due to multiple factors like ecosystem services and related monetary values were contextdependent, i.e. it was linked to geographical, ecological and socio-economic nature of the study area. The other factor was the issue of conversion of monetary values to international currency. The studies used different currency types and conducted at varied years. This work, therefore, can be extended with a quantitative analysis of the articles by including other types of database. In sum, the methodologies for the mapping, quantifying and valuation of FES are developing rapidly both from economic and biophysical valuation techniques. Even if they are developing, most of them were general evaluations which are less likely linked with decision-making processes (Additional file 1: Appendix).

\section{Additional file}

Additional file 1: Table S1. List of publication screened for FES final analysis. Table S2. Categories of the four main ecosystem services by different authors.

\section{Abbreviations}

CICES: The Common International Classification of Ecosystem Services; EC: European Commission; ES: Ecosystem Services; FES: forest ecosystem services; ha: hectare; InVEST: Integrated Valuation of Ecosystem Services and Tradeoffs; KR: Kwacha Rebased (the currency of Zambia); MEA: Millennium Ecosystem Assessment; PRISMA: Preferred Reporting Items for Systematic Reviews and Meta-Analyses; Rs: Rupees (currency of India); SJR: SCImago Journal Rank; TEEB: the Economics of Ecosystems and Biodiversity; US\$: United States Dollar; Yr:: year; ¥-: Yen (currency of Japan); ¥-: Yuan (currency of China).

\section{Acknowledgements}

We are grateful to Addis Ababa and Debre-Berhan University for their academic support to conduct this review paper. We would also like to extend our gratitude to the two anonymous reviewers who have provided us with their invaluable scientific comments and advices that have greatly improved the quality of the paper.

\section{Authors' contributions}

WM collected the materials and wrote the paper. TS has revised the final manuscript. Both authors read and approved the final manuscript.

\section{Funding}

This research received no external funding.

\section{Availability of data and materials}

Not applicable.

Ethics approval and consent to participate Not applicable.

Consent for publication

Not applicable.

Competing interests

The authors declare that they have no competing interests.

\section{Author details}

${ }^{1}$ Department of Natural Resource Management, Debre-Berhan University, Debre Berhan, Ethiopia. ${ }^{2}$ Center for Environmental Science, College of Natural Science, Addis Ababa University, Addis Ababa, Ethiopia.

Received: 3 April 2019 Accepted: 1 June 2019

Published online: 07 June 2019

\section{References}

Aerts R, Honnay O (2011) Forest restoration, biodiversity and ecosystem functioning. BMC Ecol 11:29

Alarcon GG et al (2015) Weakening the Brazilian legislation for forest conservation has severe impacts for ecosystem services in the Atlantic Southern Forest. Land Use Policy 47:1-11

Aznar-Sánchez JA, Belmonte-Ureña LJ, López-Serrano MJ, Velasco-Muño JF (2018) Forest ecosystem services: an analysis of worldwide research Forests 9:453 
Balvanera P et al (2014) Linking biodiversity and ecosystem services: current uncertainties and the necessary next steps. Bioscience 64(1):49-57

Beier CM, Caputo J, Lawrence GB, Sullivan TJ (2017) Loss of ecosystem services due to chronic pollution of forests and surface waters in the Adirondack Region (USA). J Environ Manage 191(x):19-27. https://doi.org/10.1016/j. jenvman.2016.12.069

Bernard F, de Groot RS, Campos JJ (2009) Valuation of tropical forest services and mechanisms to finance their conservation and sustainable use: a case study of Tapantí National Park, Costa Rica. For Policy Econ 11(3):174-183

Biao Z, Wenhua L, Gaodi X, Xiao Y (2008) Water conservation of forest ecosystem in Beijing and its value. Ecol Econ 69(7):1416-1426. https://doi. org/10.1016/j.ecolecon.2008.09.004

Birch JC et al (2014) What benefits do community forests provide, and to whom? A rapid assessment of ecosystem services from a Himalayan Forest, Nepal. Ecosyst Serv 8:118-127

Bojović S, Matić R, Popović Z, Smiljanić M, Stefanović M, Vidaković V (2013) An overview of forestry journals in the period 2006-2010 as basis for ascertaining research trends. Scientometrics 98:1331-1346

Braat LC, de Groot R (2012) The ecosystem services agenda: bridging the worlds of natural science and economics, conservation and development, and public and private policy. Ecosyst Serv 1(1):4-15. https://doi. org/10.1016/j.ecoser.2012.07.011

Brockerhoff EG, Barbaro L, Castagneyrol B, Forrester DI, Gardiner B, González-Olabarria JR, Lyver PO, Meurisse N, Oxbrough A, Taki H, Thompson ID, van der Plas F, Jactel H (2017) Forest biodiversity, ecosystem functioning and the provision of ecosystem services. Biodivers Conserv 26(13):3005-3035

Chan KMA, Satterfield T, Goldstein J (2012) Rethinking ecosystem services to better address and navigate cultural values. Ecol Econ 74:8-18

Costanza $R$ et al (1997) The value of the world's ecosystem services and natural capital by. Nature 387(May):253-260

Costanza R, De Groot R, Braat L, Kubiszewski I, Fioramonti L, Sutton P, Farber S, Grasso M (2017) Twenty Years of Ecosystem Services: How Far Have We Come and How Far Do We Still Need to Go ? Ecosyst. Serv. 28:1-16. https ://doi.org/10.1016/j.ecoser.2017.09.008

Crossman ND et al (2013) A blueprint for mapping and modelling ecosystem services. Ecosyst Serv 4:4-14

Cruz-garcia GS, Sachet E, Vanegas M, Piispanen K (2016) Are the major imperatives of food security missing in ecosystem services research? Ecosyst Serv 19:19-31. https://doi.org/10.1016/j.ecoser.2016.04.001

Cuni-Sanchez A, Pfeifer M, Marchant R, Burgess ND (2016) Ethnic and locational differences in ecosystem service values: insights from the communities in forest islands in the desert. Ecosyst Serv 19:42-50. https://doi.org/10.1016/j.ecoser.2016.04.004

D'Amato D, Rekola M, Li N, Toppinen A (2016) Monetary valuation of forest ecosystem services in China: a literature review and identification of future research needs. Ecol Econ 121:75-84

Daily GC (1997) Nature's services: societal dependence on natural ecosystems. Island Press, Washington, DC

De Beenhouwer M, Aerts R, Honnay O (2013) Agriculture, ecosystems and environment a global meta-analysis of the biodiversity and ecosystem service benefits of coffee and cacao agroforestry. Agric Ecosyst Environ 175:1-7. https://doi.org/10.1016/j.agee.2013.05.003

De Groot RS, Wilson MA, Boumans RMJ (2002) A Typology for the Classification. Description and Valuation of Ecosystem Services. 41:393-408. https://doi. org/10.1016/S0921-8009(02)00089-7

de Groot R et al (2012) Global estimates of the value of ecosystems and their services in monetary units. Ecosyst Serv 1(1):50-61. https://doi. org/10.1016/j.ecoser.2012.07.005

Deal RL, Cochran B, LaRocco G (2012) Bundling of ecosystem services to increase forestland value and enhance sustainable forest management. For Policy Econ 17:69-76. https://doi.org/10.1016/j.forpol.2011.12.007

Defries RS, Foley JA, Asner GP (2004) Land-use choices: balancing human needs and ecosystem Function in a nutshell. Ecol Environ 2:249-257

Delphin S, Escobedo FJ, Abd-Elrahman A, Cropper WP (2016) Urbanization as a land use change driver of forest ecosystem services. Land Use Policy 54:188-199. https://doi.org/10.1016/j.landusepol.2016.02.006

Ditt EH, Mourato S, Ghazoul J, Knight J (2010) Forest conversion and provision of ecosystem services in the Brazilian Atlantic Forest. Land Degrad Dev 21(6):591-603
Dobbertin MK, Nobis MP (2010) Letter to the editor exploring research issues in selected forest journals 1979-2008. Ann For Sci 67:1-7

Duc M, Ancev T, Randall A (2018) Land use policy forest governance and economic values of forest ecosystem services in Vietnam. Land Use Policy. https://doi.org/10.1016/j.landusepol.2018.03.028

Egoh B, Rouget M, Reyers B, Knight AT, Cowling RM, van Jaarsveld AS, Welz A (2007) Integrating ecosystem services into conservation assessments: a review. Ecological Economics 63(4):714-721

Englund O, Berndes G, Cederberg C (2017) How to Analyse Ecosystem Services in Landscapes — A Systematic Review. Ecol. Indic. 73:492-504. https:// doi.org/10.1016/j.ecolind.2016.10.009

Escobedo FJ, Clerici Nicola, Staudhammer Christina L, Corzod Germán Tovar (2015) Socio-ecological dynamics and inequality in Bogotá, Colombia' s public urban forests and their ecosystem services. Urban For Urban Green 14(4):1040-1053. https://doi.org/10.1016/j.ufug.2015.09.011

Fisher B, Turner RK, Morling P (2008) Defining and classifying ecosystem services for decision making. Ecol Econ 68(3):643-653. https://doi. org/10.1016/j.ecolecon.2008.09.014

Gaodi XIE et al (2010) Forest ecosystem services and their values in Beijing Chin Geogr Sci 20(1):51-58

García-nieto AP, García-Ilorente M, Iniesta-arandia I, Martín-lópez B (2013) Mapping forest ecosystem services: from providing units to beneficiaries. Ecosyst Serv 4:126-138. https://doi.org/10.1016/j.ecose r.2013.03.003

Häyhä T, Paolo P, Paletto A, Fath BD (2015) Assessing, valuing, and mapping ecosystem services in Alpine forests. Ecosyst Serv 14:12-23. https://doi. org/10.1016/j.ecoser.2015.03.001

Howe C, S Helen, Vira B, Mace GM (2014) Creating win-wins from trade-offs? ecosystem services for human well-being: a meta-analysis of ecosystem service trade-offs and synergies in the real world. Glob Environ Change 28:263-275. https://doi.org/10.1016/j.gloenvcha.2014.07.005

Huxham M et al (2015) Applying climate compatible development and economic valuation to coastal management: a case study of Kenya's Mangrove Forests. J Environ Manage 157:168-181. https://doi.org/10.1016/j. jenvman.2015.04.018

Joshi G, Negi GC (2011) Quantification and valuation of forest ecosystem services in the Western Himalayan Region of India. Inter J Biodivers Sci Ecosyst Serv Manage 7(1):2-11

Kanungwe FK, Quinn CH, Dougill AJ (2013) Contribution of forest provisioning ecosystem services to rural livelihoods in the Miombo Woodlands of Zambia. Popul Environ 35:159-182

Kibria ASMG et al (2017) The value of ecosystem services obtained from the protected forest of Cambodia: the case of Veun Sai-Siem Pang National Park. Ecosyst Serv 26:27-36. https://doi.org/10.1016/j.ecoser.2017.05.008

Lara-Pulido JA, Guevara-Sanginés A, Martelo CA (2018) A meta-analysis of economic valuation of ecosystem services in Mexico. Ecosyst Serv 31:126-141

$\mathrm{Li} \mathrm{H}$, Chen L (1997) A study on the hydrological effects and the precipitation chemistry of the mountainous forest ecosystem in the warm temperate zone of the northern China

Li T, Cui Y, Liu A (2017) Spatiotemporal dynamic analysis of forest ecosystem services using 'big data': a case study of Anhui Province, CentralEastern China. J Clean Prod 142:589-599. https://doi.org/10.1016/j.jclep ro.2016.09.118

Luck GW et al. (2012) Ethical considerations in on-ground applications of the ecosystem services concept. BioScience 62(12):1020-1029. https://acade mic.oup.com/bioscience/article-lookup/doi/10.1525/bio.2012.62.12.4

Mamat Z, Halik Ü, Keyimu M, Keram A, Nurmamat K (2018) Variation of the floodplain forest ecosystem service value in the lower reaches of Tarim River, China. Chin Geogr Sci 29:47-57

Milcu A, Hanspach J, Abson D, Fischer J. (2013) Cultural ecosystem services : a literature review and prospects for future research. Ecosyst Serv 18(3)

Millennium Ecosystem Assessment (MEA) (2005) Ecosystems and human wellbeing: synthesis. Island Press, Washington, DC

Moher D, Liberati A, Tetzlaff J, Altman DG (2010) Prisma Group. Preferred reporting items for systematic reviews and meta-analyses: the PRISM statement 8:336-41

Morri E, Pruscini F, Scolozzi R, Santolini R (2014) A forest ecosystem services evaluation at the river Basin scale: supply and demand between Coastal Areas and Upstream Lands (Italy). Ecol Ind 37:210-219. https://doi. org/10.1016/j.ecolind.2013.08.016 
Mutoko MC, Hein L, Shisanya CA (2015) Tropical forest conservation versus conversion trade-offs: insights from analysis of ecosystem services provided by Kakamega rainforest in Kenya. Ecosyst Serv 14:1-11

Nelson E, Mendoza G, Regetz J, Polasky S, Tallis H, Cameron DR, Chan KMA, Daily GC, Goldstein J, Kareiva PM et al (2009) Modeling Multiple Ecosystem Services, Biodiversity Conservation, Commodity Production, and Tradeoffs at Landscape Scales. Front. Ecol. Environ. 7(1):4-11. https://doi. org/10.1890/080023

Ninan KN, Inoue Makoto (2013a) Valuing forest ecosystem services: case study of a forest reserve in Japan. Ecosyst Serv 5:78-87. https://doi. org/10.1016/j.ecoser.2013.02.006

Ninan KN, Inoue Makoto (2013b) Valuing forest ecosystem services: what we know and what we don't. Ecol Econ 93:137-149. https://doi. org/10.1016/j.ecolecon.2013.05.005

Ninan KN, Kontoleon Andreas (2016) Valuing forest ecosystem services and disservices - case study of a protected area in India. Ecosyst Serv 20:1-14. https://doi.org/10.1016/j.ecoser.2016.05.001

Niu Xiang et al (2012) Economical assessment of forest ecosystem services in China: characteristics and implications. Ecol Complex 11:1-11

Ojea E, Ruiz-benito P, Markandya A, Zavala MA (2012) Forest policy and economics wood provisioning in Mediterranean forests: a bottom-up spatial valuation approach. For Policy Econ 20:78-88. https://doi.org/10.1016/j. forpol.2012.03.003

Philipp J, Brander L, Maes J, Hartje V (2013) Mapping ecosystem services' values: current practice and future prospects. Ecosyst Serv 4:33-46

Portman ME (2013) Ecosystem services in practice: challenges to real world implementation of ecosystem services across multiple landscapes e a critical review. Appl Geogr 45:185-192. https://doi.org/10.1016/j.apgeo g.2013.09.011

Power AG (2010) Ecosystem services and agriculture: tradeoffs and synergies. Philos Trans R Soc Lond B Biol Sci 365(1554):2959-2971

Rodriguez JP et al (2006) Trade-offs across space, time, and ecosystem services. Ecol Soc 11(1):14

Rukundo E et al (2018) Spatio-temporal dynamics of critical ecosystem services in response to agricultural expansion in Rwanda, East Africa. Ecol Indic 89(December 2016):696-705. https://doi.org/10.1016/j.ecoli nd.2018.02.032

Sheng W, Zhen L, Xie G, Xiao Y (2017) Determining eco-compensation standards based on the ecosystem services value of the mountain ecological forests in Beijing, China. Ecosyst Serv 26(March 2016):422-430. https:// doi.org/10.1016/j.ecoser.2017.04.016

Song C et al (2016) Spatial Assessment of ecosystem functions and services for air purification of forests in South Korea. Environ Sci Policy 63:27-34. https://doi.org/10.1016/j.envsci.2016.05.005

Spangenberg JH, Settele J (2010) Precisely incorrect? Monetising the value of ecosystem services. Ecol Complex 7(3):327-337. https://doi.org/10.1016/j. ecocom.2010.04.007
Tadesse G, Zavaleta E, Shennan C (2014) Coffee landscapes as refugia for native woody biodiversity as forest loss continues in Southwest Ethiopia. Biol Conserv 169:384-391. https://linkinghub.elsevier.com/retrieve/pii/ S0006320713004205

Tekalign $\mathrm{M}$ et al (2018) Forest cover loss and recovery in an East African remnant forest area: understanding its context and drivers for conservation and sustainable ecosystem service provision. Appl Geogr 98(September 2017):133-142. https://doi.org/10.1016/j.apgeog.2018.07.014

The Economics of Ecosystems and Biodiversity TEEB (2010) The Economics of Ecosystems and Biodiversity (TEEB). Ecological and Economic Foundations, Oxford

Tilahun M, Damnyag L, Anglaaere LCN (2016) The Ankasa forest conservation area of Ghana: ecosystem service values and on-site REDD+ opportunity cost. For Policy Econ 73:168-176

Tolessa T, Senbeta F, Kidane M (2017) The impact of land use/land cover change on ecosystem services in the central highlands of Ethiopia. Ecosyst Serv 23(December 2016):47-54. https://doi.org/10.1016/j.ecose r.2016.11.010

Uddin S et al (2013) Economic valuation of provisioning and cultural services of a protected mangrove ecosystem: a case study on Sundarbans Reserve. Ecosyst Serv 5:88-93. https://doi.org/10.1016/j.ecose r.2013.07.002

Verkerk PJ et al (2014) Assessing impacts of intensified biomass production and biodiversity protection on ecosystem services provided by European forests. Ecosyst Serv 9:155-165

Vizzarri M, Tognetti R, Marchetti M (2015) Forest ecosystem services: issues and challenges for biodiversity, conservation, and management in Italy. Forests 6(6):1810-1838

Vogl AL et al (2016) Environmental science \& policy managing forest ecosystem services for hydropower production. Environ Sci Policy 61:221-229. https://doi.org/10.1016/j.envsci.2016.04.014

Wang M et al (2018) Estuarine, coastal and shelf science potential ecosystem service values of mangrove forests in southeastern China using highresolution satellite data. Estuar Coast Shelf Sci 209(October 2017):30-40. https://doi.org/10.1016/j.ecss.2018.05.023

Xie GD, Zhen L, Cun Xia LU, Cao SY, Xiao Y (2008) Supply, consumption and valuation of ecosystem services in China. Resour Sci 38(38):1152-1161 (In Chinese)

Zhang B, LiW, Xie G (2010) Ecosystem services research in China: progress and perspective. Ecol Econ 69(7):1389-1395. https://doi.org/10.1016/j.ecole con.2010.03.009

\section{Publisher's Note}

Springer Nature remains neutral with regard to jurisdictional claims in published maps and institutional affiliations.

\section{Submit your manuscript to a SpringerOpen ${ }^{\odot}$ journal and benefit from:}

- Convenient online submission

- Rigorous peer review

- Open access: articles freely available online

- High visibility within the field

- Retaining the copyright to your article

Submit your next manuscript at $\boldsymbol{\nabla}$ springeropen.com 